\title{
From protoplasm to Umwelt: Plans and the technique of nature in Jakob von Uexküll's theory of organismic order
}

\author{
Tobias Cheung \\ Kulturwissenschaftliches Seminar, Humboldt Universität \\ Sophienstr. 22, D-10178 Berlin, Germany \\ e-mail: t.cheung@gmx.net
}

\begin{abstract}
For Uexküll, biology is the science of the organization of living beings. In the context of Entwicklungsmechanik, he refers to Driesch's and Spemann's experiments on the development of embryonic germ cells to prove that self-differentiating processes constitute organisms as natural objects. Uexküll focuses on the theory of such self-differentiating processes or organizations. The notion of organization implies for him a "technique of nature" that is capable of structuring organic and inorganic material according to plans and rules. These plans and rules are part of the overall order of the world. As preformed sign systems or codes, they determine and regulate the development and existence of individual animal subjects in their specific Umwelten.
\end{abstract}

The universe is made out of subjects and their Umwelten that are related to each other through function circles to form a plan-governed whole.

Uexküll 1928

\section{Introduction}

After various experiments on the nervous system and the initiation of correlated muscle movements of sea-urchins, jellyfishes, octopods and other invertebrates in Heidelberg and Naples, Uexküll published in 1905 his first book: Leitfaden in das Studium der experimentellen Biologie der Wassertiere. The first chapter of the book focuses on "problems". One of the main problems for experimental biologists is, 
according to Uexküll, to explain the "connection that combines the operations (Leistungen) of all organs", that is to say from the stimulus of receptor organs to their "answer" in effector organs (Uexküll 1905: 9). Uexküll calls this connection a "reflex" or a "reflex arch".

A reflex is a "chain of intercalated independent operations (Einzelleistungen)" between the receptor and effector organs of a single organism. The reflex "passes" through a certain number of organs, and the reflex arch represents the totality of these organs. The "succession" of organs is always the same: receptor, nerve, center, nerve, effector. Each animal exists thus as a "well-ordered bundle of reflexes" (geordnetes Bündel von Reflexen), and experimental biology retraces their mechanisms (Uexküll 1905: 9). However, experimental biology has to explain "more" than these mechanisms because the "effectiveness" and "purposefulness" of reflex arches makes it "necessary" to refer to a "construction plan" (Bauplan) (Uexküll 1905: 6667). Only if biologists provide a theoretical basis for such a "plan", does biology acquire the "foundation" (Grundlage) necessary to be a natural science on par with chemical physiology, chemistry and physics. Biological knowledge thus depends on both experimental and theoretical (or "analytical") research (Uexküll 1905: 96).

Experimental biologists refer to explanations through descriptions and proofs, and theoretical biologists through definitions and their logical consequences. However, Uexküll thinks that a good scientist has to work in both ways. Scientific definitions must be in accordance with experimental proofs and descriptions, and experiments are performed according to questions that are themselves related to definitions and their analytic context. But experiments cannot explain the correctness of definitions and their consequences. Rather, theoretical biology has to develop the explanatory framework within which experimental biology can be interpreted. Biology thus needs, after a sufficient set of experimental proofs and descriptions, first of all a theoretical "foundation" to become a natural science (Uexküll 1905: 125-130). In an article of 1903 on the biological Bauplan of the worm-like Sipunculus nudus, Uexküll defines the general objective of "biological" research:

Biology is the science ${ }^{1}$ of the organization of living beings. Organization is called the conjunction of different elements according to a uniform plan for a common

1 I translate 'Lehre' as 'science'. 
effect. Biology has thus to search in each living form (Gebilde) for the plan of its construction and for the elements of this construction. (Uexküll 1903: 269)

Uexküll's answer to the problem of organismic "organization" is that "plans" can explain organismic order, while "mechanical" causation cannot; biologists have to discover these "plans" in nature, and biology is also "the science of the Planmäßigkeit of all living beings" (Uexküll 1928: 292). Explanations that refer to "plans" imply for Uexküll that there is something like a "technique of nature" (Naturtechnik) as a general principle for order generating processes in organic bodies.

The next sections reconstruct Uexküll's notions of a "plan" and "technique of nature" (Naturtechnik). After some remarks on Uexküll's epistemology in the second section, I will outline the experimental settings of two "proofs" that Uexküll uses as standard references to explain organic order. The difference between technical and mechanical biology is the theme of the fourth section. In the fifth section, I will focus on Uexküll's general scheme of action. Finally, metatheoretical assumptions and analogies of order are discussed in the sixth section.

\section{Uexküll's epistemological claims}

As for Kant, subjectivity means for Uexküll first of all that there is an agent that constitutes its own >reality<. However, Uexküll asks not only for possible forms of judgments, but also for the existential mode of the agent of knowledge. For him, explanations of this mode basically refer to "experimental research" in biology (Uexküll 1928: 130). Such research is always performed by subjects, but biologists might be able to "minimize" and control subjective factors that are involved in the production of scientific knowledge:

Objective events (Vorgänge) are in general regarded as events that occur among objects with no consideration for any subject. But we have to admit that we do not know such events, because it is always our own subject that observes the events, and this subject can never be eliminated (ausschalten). It can thus only be a question of reducing the subjective accessories (Zutaten) to a minimum. (Uexküll 1926: 179) 
Uexküll thinks that scientists not only reduce "subjective accessories" in experiments, but even go one step further. He is convinced that experiments in biology "force" us to reconstruct a reality that we could not have "imagined" before, that is to say to rationalize constitutive "factors" of other organized orders than ours, orders that are at the same time organized and organizing. If scientists reconstruct "plans", they can switch from one "subjective" perspective to another, although they can only sketch very general aspects of these "worlds" and their agents, the "animal subjects". It is thus Uexküll's vision to glimpse into "worlds" that have no windows before biology takes form and to sketch the constitutive principle of natural subjects:

Kant thought of causality as a part of the constitutive activity of understanding (Verstand). However, Planmäßigkeit was for him a part of the regulative use of reason (Vernunft). One could thus have the impression that a plan could never be an integral part of an object, but just an imagined (hinzugedachte), though necessary human rule. Driesch has examined this question in detail. He proved that Planmäßigkeit should also be a part of the constitutive properties [of objects]. This problem is thus removed (beseitigt). (Uexküll 1928: 293-294) ${ }^{2}$

Uexküll claims that biological research changed the explanatory status of the regulative judgment. Kant could only refer to the facts of "descriptive natural scientists". But experiments can "prove" that something is the "fact" beyond these descriptions. Biologists might be able to find scientifically a model of the natural constitution of knowing subjects and to enlarge this model to a common explanatory scheme for all natural subjects that are capable of "actions" or "acts", although such an explanatory scheme of an organizing "factor of nature" is, in a strict sense, just an adequate scheme for "our" thinking:

Neither the construction plan nor the formation plan have anything to do with the real factor of nature (Naturfaktor) that forces physico-chemical processes to take certain paths. Rule and plan are just the form (Form) through which

\footnotetext{
2 Cf. Uexküll 1931a: 385: "Epistemologically we can assume that we have two thought forms (Denkformen) at our disposal to connect (verknüpfen) the phenomena of the world with each other: First, the causality, that is to say the relation between cause and effect. Second, the Planmäßigkeit, that is to say the relation between the part and the whole." See also Uexküll 1922: 137 and 1923: 60.

3 Cf. Uexküll 1923: 60.
} 
we recognize the effects of this factor of nature. The factor itself is totally unknown to us. (Uexküll 1921: 10)

Uexküll's position between epistemological and ontological claims has thus something to do with "adequate" explanations of experimental settings and descriptions of phenomena. ${ }^{4}$ For Uexküll, experimental settings and descriptions of objects that belong to organisms "force us" to refer to a certain model of organismic order. These models are, for Uexküll, somehow out there in nature, but we cannot know for sure if they are >really< that what they seem to be.

Uexküll thus relates the deconstruction of the knowing subject to the "experimental investigation" of the order of organic bodies. For Uexküll, this investigation results first of all in the formulation of a new problem, the one of the regulation of cell development.

\section{The regulation of cell development and its two experimental proofs}

This section has two main parts. In the first part, I will reconstruct some aspects of the scientific environment that influenced Uexküll's theory of organic development, which focused on two experimental "proofs". In the second part, I will discuss Uexküll's interpretation of these "proofs".

Around 1900, research on the development of embryonic cells and discoveries of chromosome movements changed perspectives on the evolution, morphogenesis and hereditary factors of organic bodies. This change began already in the second half of the 19th century, and one of its main actors in the German context was Wilhelm Roux. Like Hans Driesch, he was a disciple of Ernst Haeckel.

In 1888, Roux killed one of the blastomeres of a two-cell-stage of a frog egg with a hot needle. The uninjured cell formed an abnormal gastrulation and developed into a cluster of cells that was interpreted as a half-embryo. The result of the experiment seemed to prove Roux's theory of "determinants" (Determinanten) that are differentiated after the cleavage of the primary germ cell, so that each cleavage changes the developmental potential of cells. This mosaic

4 See also Thure von Uexküll 1980: 149-151. 
theory of determining factors in cleavage cells goes back to Weissman's theory of the differentiation of germ cells.

Roux's experimental setting initiated not only a series of new experiments to prove the mosaic distributions of determinants in cleavage cells. It also represented a shift in general interest from rather descriptive comparative mophogenetic studies to experimental research. Roux called this research program "developmental mechanics" (Entwickelungsmechanik).

However, the reiterations of Roux's experiment also resulted in new critiques. The development of the uninjured cleavage cell seemed to depend on the influence of the remaining dead cell. One of the main problems was therefore to separate the two first cleavage cells without killing both of them.

A group of scientists of the Stazione Zoologica in Naples focused on this problem. From 1898 to 1903, Jakob von Uexküll was the director of the center's physiology department, but he also worked until 1900 with Wilhelm Friedrich Kühne at the university of Heidelberg. Hans Driesch began his work at the institute in 1891. In the same year, one of his colleagues, Curt Alfred Herbst, developed a new technique to separate the blastomeres of a sea-urchin egg in using calcium-free seawater. ${ }^{5}$

Driesch shook the embryos to separate the blastomeres, but he also used Herbst's method. ${ }^{6}$ The isolated blastomeres developed not into Roux's half-embryos, but into completely formed, albeit smaller seaurchin larvae of Echinus microtuberculatus. In 1892, Driesch published the results of his experiments in the Zeitschrift für wissenschaftliche Zoologie. ${ }^{7}$ He concluded that germ cells contain not a mosaic of determining factors that are separated mechanically during the cleavage, but regulative properties instead. These regulative properties in embryonic cells belong for Driesch to a "harmoniousequipotential system" that is active in cells of the blastula. Its formative or "prospective potential" changes during the cell development. Driesch thus distinguished between the "prospective" and the "actual potential" of cleavage cells. In his Philosophy of the Organic, which was published after his Gifford-lectures in 1909, he referred to a non-

A different technique had been used by H. Endres (and later on also by Spemann) in 1895. Endres laced the two cells of the blastula.

Cf. Penzlin 2000: 444-446.

7 Driesch 1892. 
mechanical, "individualizing causality" that develops as a selfdifferentiating "entelechy" to explain the theoretical framework of regulative properties in embryonic cells. ${ }^{8}$

Hans Spemann also focused on the regulative properties of early cell developments. Spemann, a disciple of Theodor Boveri, worked first in Würzburg on the development and formation of lens cells. In 1901, he began to use a new technique to transplant cell fragments from one embryo (the donor) into another embryo (the host) with a micropipette. After he went to Freiburg to take the chair of Franz Dorflein in 1919, Spemann performed various experiments to understand the development of the amphibian nervous system. His main interest was to specify the moment in which embryonic cells loose their totipotent regulative properties. While there are only few visible differences between the cleavage cells of the blastula in amphibian embryos, these cells are slowly rearranged in the late gastrula phase to form three germ layers (ectoderm, mesoderm and endoderm). The determination of the fate of embryonic cells thus seemed to happen between the early and the late gastrula.

One of the first visible organ systems during gastrulation is the nervous system. Spemann and other investigators, such as Johannes Holtfreter, knew that detached or explanted parts of the presumptive neural tube cells from an early gastrula do not develop into neural tissue. However, presumptive neural tube cells of the late gastrula had that potential. Because the neural plate always appeared in a constant position, Spemann suggested that the invaginated cells at the dorsal lip (which form under normal conditions the roof of the achenteron directly beneath the neural tube cells) are able to determine the fate of ectoderm cells.

The crucial experiment to prove that there is something like a "differentiating" or "organizing center" in the gastrula of amphibian eggs was performed by Spemann and his doctoral student Hilde Mangold in 1924. ${ }^{9}$ They used two species of salamanders with a different pigmentation (the nearly white Triturus cristatus and the brownish Triturus taeniatus) to retrace the development of the dorsal lip cells that had been transplanted from the donor's blastopore into

8 For Driesch's theory of self-differentiation and cell development see Mocek 1998.

9 For a detailed description of the experiment see Moore 1972: 265-274 and Fässler 1997. 
the opposite ventral ectodermis area of the host embryo in an early gastrula. Not only did the host's blastopore invaginate normally, but the donor cells also developed into a small archenteron and later produced neural folds. The neural folds were composed of host cells. Under normal conditions, these host cells would have developed into an epidermis. In addition, the new folds occasionally almost formed an entire embryo.

Spemann interpreted this effect as an "induction" of an organizing center in the dorsal lip, and called this center an "organizer" (Organisator). After Spemann's and Mangold's experiment, it seemed that, in the early phase of gastrulation, presumptive ectoderm cells have an equal "prospective potential", and that their fate depends on the influence of an "organizer" situated in the area of the dorsal lip.

Uexküll refers frequently to Driesch's and Spemann's experimental "proofs". ${ }^{10}$ However, these "proofs" are part of his own theory of cell development. He distinguishes three phases or "steps" (Schritte) during the development of embryonic cells: First, the "cell differentiation" (Zellteilung) of germ cells in the "mother cell" (Mutterzelle) or the "primary shoot" (Primärsproß), second "tissue differentiation" (Gewebeteilungen) and third "organ formation" (Organbildung). ${ }^{11}$

Cell differentiation, tissue differentiation and organ formation represent, in general, the three basic steps of the organismic "Gefügebildung" (structure formation). 12 Gefügebildung is the "temporal form" (Zeitgestalt) of organic bodies. During Gefügebildung, organic bodies develop gradually into a "close mechanism" that characterizes the "spatial form" (Raumform) of the adult organism (Uexküll 1922: 129). The temporal form always expresses a directional process or a "path" (Weg) that ends in the formation of a spatial form. ${ }^{13}$ Uexküll thinks that such a directional process is similar to a "technical process" that operates according to a plan. Each developmental phase that characterizes the "temporal form" of the Gefügebildung could thus also be

\footnotetext{
10 For references to Driesch and Spemann, cf. Uexküll 1920: 68-69; 1927: $12-$ 14; 1928: 229-231 and 249-253; 1929a: 150-155; 1929b: 41-43; 1931a: 388; 1937: 197 and 1938: 137.

11 Cf. Uexküll 1922: 144-156.

12 'Gefüge' could be translated as "form" or "structure".

13 Cf. Uexküll 1928: 244: " [...] each spatial relation in the body results from a specific process (formative process)".
} 
interpreted as a "technical path" (technischer Weg). ${ }^{14}$ However, only the organismic "plan" is itself "creative" (bildend) or "active", while the technical "plans" of human machines are just "passive" representations of mechanical connections. ${ }^{15}$

For Uexküll, each cell differentiation is regulated by "partial plans" that depend on the general plan of the organismic "organization". ${ }^{16}$ The Gefüge that results from the developmental process finally "inhibits" (hemmen) the process: "Gefüge inhibits the Gefügebildung"(Uexküll 1922: 146-147). ${ }^{17}$ At the end of the tissue formation, the Gefüge forms a functional unit of organs that interact as a "close mechanism". 18

The Gefüge of the protoplasm and of the growing organism is thus at the same time a material Gefüge of visible structures and of "immaterial" plans that "induce" the Gefügebildung according to certain "rules". This is the "technique of nature" that appears during organic development. ${ }^{19}$

Uexküll thinks that it is "impossible" for humans to "imagine" how immaterial plans could "act" on matter. However, he points, in a similar way to Kant in his Third Critique, to the possibility that phenomena of the Anschauungsraum "force" us to refer to plans and their "over-mechanical" faculty to produce temporal forms:

I wanted to show that [...] the time forms are not problematic any more if I take as a basis the Anschaunngswelt instead of the Vorstellungswelt, because they are a necessary consequence of the Anschauungswelt itself. The Anschauungswelt encloses (beherbergen) a broader manifoldness than the Vorstellungswelt [...] (Uexküll 1927: 25) ${ }^{20}$

14 Cf. ibid., p. 145.

15 Cf. Uexküll 1938: 58. "If the performance (Arbeitsleistung) of machines is called 'mechanics' (Mechanik), but the construction and form generating process 'technique', we can make a difference between the 'mechanics of nature' and the 'technique of nature'." See also Uexküll 1929b: 39.

16 In some germs, however, specific groups of cells or "secondary shoots" (Sekundärsprosse) differentiate very early. Uexküll calls them "mosaic germs" (Mosaikkeime). (Cf. Uexküll 1929a: 41.)

17 Uexküll (see also Uexküll 1905: 9) refers to experiments on lens formations and their interpretations by Bernhard Dürken and H. Wachs.

18 Cf. ibid., p. 149.

19 Cf. ibid., p. 155.

20 However, Uexküll does not always make a clear distinction between Vorstellungswelt and Anschauungswelt. 
But the Anschauungswelt of modern science is different from the descriptions of Kant's observer. Experimental research, "totally unknown in Kant's epoch" (Uexküll 1923: 60), "proved" that there have to be self-regulative processes in nature. These "proofs" are related to the experiments of Driesch and Spemann. Uexküll needs them for two "facts".

First, Driesch's experiments on the development of sea-urchin embryos "proved" that the regulative factor in the germ is "independent" from its material expression.

Only the experiment has clarified it. If, as has been assumed, there would be a germ Gefüge that is similar to the one of the future body, it must be divided in half when the germ is divided in half, and both halves must produce two half animals. This is not the case: Half a germ always produces an entire animal, although of half height. This insight is due to Driesch who scattered the whole science of development (Entwicklungslehre). (Uexküll 1920: 68-69)

There is thus nothing "folded" or "tangled" (verwickelt) in the germ that could be seen by a comparative anatomist who searches "corporal forms". Rather, the "lower anatomy of corporal forms" has to be replaced by a "higher anatomy of generating forms (Bildungsformen)" (Uexküll 1927: 23). The anatomy of generating forms must define the relation between immaterial plans and cell differentiation. But such an interaction cannot be explained by mechanical laws. Generating forms are temporal forms, and they appear as technical paths that produce order. There is a second experimental "proof" that this dynamic process is regulated through different "organizing plans":

Spemann could show that an >organizing center appears in the beginning of the gastrulation of Triton in the upper lip of the blastoporus from which, as he says, emerge >differentiating currents` (Differenzierungsströme) that impose on the hitherto undifferentiated cells of the outer germ layer a new direction of formation (Gestaltungsrichtung). From cell to cell run new impulses, as I expressed it, to force a new technical path on them. (Uexküll 1929a: 157) ${ }^{21}$

The experiments of Spemann and Driesch thus force us to develop a new imaginative space of regulative processes. To define life cannot mean, as Uexküll highlights in his 1927 paper with the title Definition

21 Spemann (Uexküll 1929a: 153) has thus "proved the independency of the impulse from matter in the most convincing way". 
des Lebens und des Organismus, "to construct logical notions about the essence of life" (Uexküll 1927: 1). Rather, one has to "refer to" (darzulegen) and discuss the "scientifically examined experiences (wissenschaftlich gesichteten Erfahrungen) that characterize life". ${ }^{22}$ It is "impossible" to reduce temporal to mechanical forms. But scientific modeling can get very far:

If the ideal that I have in mind, that is to say to confine the formation process (Formbildung) in the test tube, is reachable, cannot be said. But it is possible to come much closer to the problem if one has found the right question. (Uexküll 1920a: 179)

The "right question" is for Uexküll the one that investigates the Planmäßigkeit of organic order. The answer to the question must be a scientific model that mediates between descriptions, experimental proofs and definitions.

\section{From development to existence: the scientific model of organismic self-differentiation}

The whole organism, the "cell", for Uexküll is an autonomous unit, or an "Autonom" (Zellautonom), as he calls it, with different prospective potentials. $^{23}$ It is the "elementary organ" (Elementarorgan) $)^{24}$ of the organism, its "living module" or "building block" (Baustein) ${ }^{25}$ that "acts" according to its own "plan" as a "cell subject" $(\text { Zellsubjekt })^{26}$. It cannot "act" in a dead, but only in a "living organism". ${ }^{27}$

Each cell contains a "nucleus" (Kern) and "protoplasm". Along with the nucleus, the protoplasm represents the "matter of life" (Lebenstoff). ${ }^{28}$ No man-made machine uses "protoplasm" to structure

22 Uexküll 1927: 1. A similar argumentation can be found in the beginning of 'Technische and mechanische Biologie' (Uexküll 1929a: 129).

23 Cf. Uexküll 1928: 177.

24 Cf. Uexküll 1928: 176.

25 Uexküll 1928: 177.

26 Cf. Uexküll 1929b: 41.

27 Cf. Uexküll 1929b: 41.

28 In the following paragraphs, I will use the word "protoplasm" in brackets if it means protoplasm and nucleus. 
its units. Only organisms are self-regulative, and only organisms are made out of "protoplasm". 29

Research on the relation between the "protoplasm" and the organism is "basic" and necessary for any progress in biological knowledge. "Protoplasm" is for Uexküll "not a substance in the common sense, but a mixture (Gemenge) of substances in a state of perpetual metabolism". 31

Uexküll's answer to the question whether "the physical laws of metabolism" or the "organization" of organisms could explain the "origin" of a "perpetual regeneration" in a self-regulative order is clear: there must be a ruler that "coordinates" (regelt) the processes of formation and maintenance, and there must also be a ruler if these processes are in disorder. Without a ruler, processes could not be "harmonized", they would "run out" (sich tot laufen) and end in disorder. ${ }^{32}$

There are two different general plans in all organisms: one for "formation processes" (Gestaltungsvorgänge) and one for "regeneration processes" (Regenerationsprozesse) in the larger sense, that is to say processes that also include metabolism. The first one is the "development plan" (Entstehungsplan) or "active edification plan" (aktiver Erbauungsplan), and the second one is the "maintenance plan" (Betriebsplan) or "active construction plan" (aktiver Bauplan). ${ }^{33}$ While the development plan is the plan of the temporal path of the organism's formation, the maintenance plan is basically a "performance plan" (Leistungsplan) ${ }^{34}$ of a "functional unit" (funktionelle Einheit) ${ }^{35}$ between organs:

Only if the organism is entirely developed and its performance (Leistung) has begun, does the active construction plan that rules the regenerative processes take the place of the active edification plan. (Uexküll 1927: 22)

Cf. Uexküll 1927: 18 and 1928: 146.

Cf. ibid.

Ibid.

Cf. Uexküll 1927: 18-21.

Cf. Uexküll 1929a: 42 and 1938: 135. Uexküll (1929: 39) also refers to the "active construction plan" as a "life factor" (Lebensfaktor) because "it maintains the corporal mechanism" constantly in its functional order.

34 Cf. Uexküll 1938: 135.

35 Uexküll 1922: 156. 
Both general plans are "active" because they initiate constructive processes. They are both — as an "edification manager" (Bauleiter) or as a "maintenance manager" (Betriebsleiter) — rulers of the cell subject. Uexküll calls the first one "organizator" (Organisator) ${ }^{36}$ and the second one "mechanizator" (Mechanisator) ${ }^{37}$. Both plans produce a passive "construction plan" of mechanical structures, but only the Gegengefüge of the "mechanizator" is a "functional unit" of organs. Each plan acts "independently" and is "blind" to the other. ${ }^{38}$ However, they are "correlative" because the Gefüge of the Bauplan is the Gegengefüge that inhibits the formative processes of the $E r$ bauungsplan. 39 They "act" independently and yet in harmony as two plans that are necessary for organismic life. There is no functional unit without formation, and no temporal form exists without its reproduction in functional units. Within the limits of possible structural variations, reproduction is thus just the repetition of the necessary conditions of organic existence, from the Erbauungsplan to the Bauplan, and from the Bauplan to the Erbauungsplan.

If the "appropriate material" is available, the perpetual regeneration (metabolism) of the organism and the repetition of its two major plans - the formation plan and the construction plan - can produce "normal" results. However, malformations appear "naturally" because of the blindness of the partial plans to their overall plan. There might not be enough material or space for the proper development and functioning of parts, but other parts do not "adapt" to this situation. If such a problem occurs during the development of the organism, serious malformations can result because the Gegengefüge of the Bauplan cannot inhibit and "correct" developmental processes (Uexküll 1929a: 40-42).

That life is basically a dynamic and continuously repeated "big cycle" between Erbauungsplänen and Bauplänen, with short phases of deconstructions or "dissolutions", becomes most visible in unicellular organisms or "protoplasmic animals" (Protoplasmatiere). ${ }^{40}$ Amoeba, infusoria, and especially paramecium and Plasmodium vivax, are for

Cf. Uexküll 1923: 58-59.

Cf. Uexküll 1929: 29.

38 Cf. Uexküll 1929a: 40-42. For the "blindness" of plans, Uexküll refers to Curt Alfred Herbst's experiments on the regeneration of crayfishes (cf. Uexküll 1929a: 40).

39 Cf. Uexküll 1929a: 42.

40 Cf. Uexküll 1928: 148. 
Uexküll standard reference objects. ${ }^{41}$ These organisms cannot form a functional unit of different organs. Rather, formative and constructive periods succeed each other constantly during their life. Infusoria "form a vesicle around the nutrient drop and transform it successively into a gullet, a stomach, an intestine and finally into an anus" (Uexküll 1929b: 73). ${ }^{42}$

In pluricellular organisms, and especially in higher animals, a single formative period is followed by a functional unit of various organs. However, in the beginning, there is just "protoplasm" that contains the "primary material" (Urmaterial) (Uexküll 1938: 141) of a "seemingly unlimited formative potential (Bildungsmöglichkeit)" (Uexküll 1920b: 178).

In this primary material, "ferments" initiate "specific processes" that can express various "properties" (Eigenschaften) of the "protoplasm" (Uexküll 1920b: 178). The ferments are released from the nucleus through "impulses", but they "act" also as "stimuli" on the nucleus. ${ }^{43}$

The impulses always appear as "impulse systems". They initiate the release of ferments, and this "act" is a non-mechanical or "immaterial" effect. ${ }^{44}$ Impulses thus "act" as "non spatial initiators of spatial processes" (Uexküll 1928: 245). Their influence on the protoplasm is not a physiological, but a "biological event" that expresses the "potential" of the "cell subject" and its "subject rule" (Subjektregel) to develop into and exist as an organism. ${ }^{45}$ The "animal subject" represents "the new natural factor (Naturfaktor) that biology introduces" (Uexküll 1931a: 389). However, there are other "factors" that are active during the cell development.

"Factors" can be characterized by their "faculty to impose a formative process on a mechanical Gefüge" (Uexküll 1928: 245). Uexküll defines the role of genes as dependent "factors" of the cell subject. There are various versions in his texts of how they operate during the formation processes. In an article from 1920, Uexküll

41 Cf. Uexküll 1920a: 147-148; 1920b: 73; 1922: 133; 1929b: 39; 1931a: 387 and 1938: 137-140.

42 For Uexküll's analysis of the different life periods of Plasmodium see Uexküll 1922: 133.

43 Cf. Uexküll 1920b: 72-73.

44 Cf. Uexküll 1920b: 178.

45 Uexküll (1923: 60) also calls the "subject rule" the "idea of the developing subject". The impulse systems are the "imperatives" of this development. (Cf. Uexküll 1920a: 177.) 
pointed to the double role of genes to "act" as "corporal properties" and to "obey" impulses that "act" non-mechanically. Genes form "autonomous elementary units" and are "probably situated in the coloured substance of the nucleus in the germ cell". During the cell division, the genes are distributed among the new cells, and the "final cells accommodate (beherbergen) only genes that are necessary for the construction of their specific tools" (Uexküll 1920b: 72). Uexküll also identifies genes with specific units or "chromomeres" that "compose" the chromosomes of the nucleus (Uexküll 1922: 140). ${ }^{46}$ Each "chromomere" or gene has a specific effect on the protoplasm and represents a "firmly circumscribed property" (fest umschriebene Eigenschaft) of the cell. ${ }^{47}$

Genes thus operate as developmental, regenerative and hereditary "factors". They release different sequences of ferments according to sequences of impulse series or "act" themselves as ferments:

It is very instructive to combine the theory of organizators with Mendel's theory. Mendel found that there are developing structures (Anlagen) as autonomous factors in the germ of living beings for their future properties. His theory says nothing about the way in which these factors reach their goal (sich durchsetzen). We know from recent research, especially from Morgan and his school, where we have to search for these >genes $<$, as these factors are called; they are situated in the chromatin stripes of the nucleus of the germ cell. In general, genes are regarded purely as matter. They are supposed to have the ability to act (wirken) as ferments when they enter into the protoplasm of the cell body and to initiate certain processes [...] It is clear that these initiations or simpulses have to occur in the right combination and in the right succession to prevent all processes from becoming disordered. This is where Spemann's theory of organizators which rule the succession of form generating processes through their law-making interventions comes into play (gesetzgebendes Eingreifen). (Uexküll 1923: 59) ${ }^{48}$

46 For the role of the chromosomes as hereditary factors and during the mitosis, see Uexküll 1928: 241-247 and 296-301.

47 Uexküll 1922: 140. Uexküll refers also to Wilhelm Johannsen's definition of the "genotype" to characterize the "members" of a "race". The "genotype" is for Uexküll more characteristic to identify the "race" than the "properties of the developed body". (ibid.)

48 For references to Morgan and Mendel see Uexküll 1927: 40, 1928: 240-247 and 1938: 140 . 
After the Gefüge of the Bauplan has been developed, the "role" of the genes ends. During the construction period, they only serve the regeneration of "destroyed or injured tools". 49 The "role" of the genes is thus very similar to that of the organizers which "dissolve" into partial organizers to control certain "germ areas" (Keimbezirke) until the end of the formative period. ${ }^{50}$ In a late article of 1938, Uexküll introduced a new organizing element, the "commander genes" (Obergene) (Uexküll 1938: 141-143). After the formation of the blastema, the commander genes "determine" the "activity" of the "obeying genes" (Untergene) to form specific tissues in certain cells (Uexküll 1938: 143).

When the functional unit of the "cell machine" starts to work, the "nucleus" becomes the "autonomously ruling chemical center of the cell" (autonom regierendes chemisches Zentrum) (Uexküll 1928: 183). It releases various ferments that maintain the metabolism of the cell (Uexküll 1928: 183). As during the formative period, "impulse systems" initiate the release of ferments in groups and in certain sequences:

The autonomous center of the cell is hit by a differentiated impulse, or, more correctly, by a differentiated series of impulses that compel (veranlaßt) the nucleus to regulate the metabolism in the protoplasm in such a way that certain products are released into the body of the cell. Together these products form a functioning mechanism. (Uexküll 1928: 183-184)

The "differentiated" or "regulated impulse series" that appears during the construction period results from the activity of the "mechanizator". The mechanizator "makes a certain choice (Auswahl) within the bundle of ferments (Fermentbündel) [of the nucleus] [...] and forces the chosen ferments to appear in a certain succession" (Uexküll 1928: 184). Missing products for metabolistic processes and products for regenerative processes are available from the "basic tissue" that extends itself through tiny "protoplasmic bridges" over the whole body of the organism (Uexküll 1928: 184-185).

In analogy to Johann Müller's specific energy, Uexküll refers to "biological factors" to describe the "initiation" (Auslösung) of move-

\footnotetext{
49 Cf. Uexküll 1920b: 73.

50 For the relation between partial organizers and "germ areas" Uexküll refers to the experiments of Hermann Braus (1867-1920) who worked with Hans Spemann in Würzburg. (Cf. Uexküll 1938: 141-142.)
} 
ments in cells and organs, especially of muscle contractions. ${ }^{51}$ During the construction period, "factors" are, in general, necessary to "start" and maintain the operational mode of the mechanic apparatus of the organism. They "act" through impulses, and Uexküll calls these impulses "performative impulses" (Leistungsimpuls) because they function as "signs" that mediate between the ruler and the mechanical movements (Uexküll 1928: 186-187). Uexküll thus integrates performative impulses as "signs" into a general scheme of organismic "action".

\section{The general scheme of action: Self-regulation and the function circle}

For Uexküll, each "action" (Handlung) can be described as a "combined movement" ${ }^{52}$ that establishes certain "relations" (Beziehungen) between various agents. The relation is itself an "act" or an "effect". One entity "acts" on or "effects" (wirkt) the other. ${ }^{53}$ Objects "act" on objects mechanically, objects on "subjects" through a "stimulus", "subjects" on objects through an "impulse" and "subjects" on "subjects" through an "induction". 54

Inductions occur if "two complementary factors" are present, and if one "calls" (ruft) the other. ${ }^{55}$ Uexküll often refers to the induction of "lens formations" through presumptive retina cells that result in "complete functional units" of eyes. ${ }^{56}$ However, how the "call" acts on a "factor" or a "plan", is unknown.

All relations in which "subjects" are involved are "biological". There are three of them: stimuli, impulses and inductions. During the formation and construction period of the organism, stimuli, impulses

51 Cf. Uexküll 1928: 185-186.

52 Cf. Uexküll 1903: 276.

53 In the context of perception and action, Uexküll (1931a: 389) also describes the relation between "action" and "reaction" as a "question and answer game".

54 Cf. Uexküll 1931a: 388.

55 Cf. Uexküll 1931b: 331. Uexküll (1931b: 330) also describes induction as a "strange psychoid act" (merkwürdiger psychoidaler Vorgang).

56 Cf. Uexküll 1929b: 43 and 1931a: 389. In 1901, Spemann published an article on lens formation in the neural stage of Rana fusca. He cauterized the presumptive retina cells and observed that the eye and the lens was missing on the operated side of the tadpole. 
and inductions are related to each other through a processing scheme. This scheme is a variation of a reflex scheme and dates back to Uexküll's early works on the contraction of muscles in invertebrates. ${ }^{57}$ However, the organism is not a "skillful intertwined bundle of reflex arches with perfectly built receptors and effectors in an autonomous machine that responds through its own operations to the influences (Einwirkungen) of the outer world" (Uexküll 1928: 147). Rather, Uexküll's scheme involves a threefold relationship between reflex mechanisms, signs and subjects. Such a relationship is "organic" because relations depend on the intervention of the "subject" and are thus "indirect" instead of being "direct" in inorganic relations. 58

Within an organism, Uexküll describes organic relationships in general as "individual function chains" (individuelle Funktionsketten) with three "links" (Glieder): "reception - conduction of stimuli effect" (Rezeption - Erregungsleitung - Effekt) or "perception regulation - action" (Merken - Steuern - Wirken). ${ }^{59}$

The relation between organisms is for Uexküll a relation of an animal subject to its Umwelt in which other subjects appear as objects. ${ }^{60}$ There is only induction between organisms if one organism uses "parts" of the other for its development and existence. Each organism thus always "acts" within its own function chain.

In such a function chain, stimuli can operate as "Merkzeichen" (perception clues), and "impulses" as "Wirkzeichen" (action clues). Within the "world" that surrounds the subject, Merkzeichen become "Merkmale" (perception marks), and Wirkzeichen (as "products" or "effects") "Wirkmale" (action marks). ${ }^{61}$ Merkmale and Wirkmale constitute the "Umwelt" of the subject. They are "set out" (hinausverlegt) by the subject. ${ }^{62}$

As stimuli and impulses, perception and action clues play a performative "role" for the expression of the subject rule. The Wirkzeichen "extinguishes" or "destroys" (vernichtet) the Merkzeichen that

Cf. Uexküll 1903: 270.

Cf. Uexküll 1920b: 84.

Cf. Uexküll 1920a: 175.

For semantic implications of Uexküll's theory see Kull 1998.

Ibid.

62 Cf. Uexküll 1931a: 389. 
comes from the "object" or the Gegengefüge. 63 A pattern or a "plan" of the animal subject corresponds to each perception clue, and this "Merkplan" (perception plan) with its Merkzeichen induces a complementary "Wirkplan" (action plan) with its Wirkzeichen:

The perception plans induce in the action organ the action plans that are complementary to them, and the impulses of the action organ carry out the right innervations. (Uexküll 1903: 390) ${ }^{64}$

Merkzeichen thus initiate, as "performative impulses", Wirkzeichen through the intervention of a subject. ${ }^{65}$ Each organismic subject expresses itself through these relations.

If the subject is regarded as the center of its perceptions, it exists within an "Umwelttunnel" in which its "Umwelt" is made out of Merkzeichen and Wirkzeichen of the Gegengefüge of the surrounding objects. ${ }^{66}$ In this monadic Umwelttunnel, other organismic subjects can only "appear" as marks and clues.

Uexküll sketches various schemes of the relationship between Merkzeichen, Wirkzeichen and the subject. In an article of 1931, he calls this relationship a "function plan" and refers to the example of an ape and an apple (Fig. 1).

In a different version, that is often referred to, the inductive process is not indicated and the clues are generalized to "worlds" that seem to characterize the outside world of the "animal subject". However, the scheme is somehow misleading because it is not clear what the inside of the "inner world" of the subject is. Uexküll calls this scheme a "function circle" (Fig. 2).

63 In the scheme of the ape and the apple (Fig. 1), the "touch mark" (Tastmerkmal) of the apple is "extinguished" (ausgelöscht) through the "bite" of the ape. For Uexküll the main problem of "complicated actions" is to find the "right action mark" (richtige Wirkmal) that extinguishes the perception mark (Uexküll 1931a: 389).

64 Cf. Uexküll 1931b: 331.

65 Cf. Uexküll 1928: 187.

66 Cf. Uexküll 1920a: 176; and 1928: 108. Instead of Umwelttunnel, Uexküll (cf. 1920a: 176) also uses the word "Lebenstunnel" (life-tunnel). 


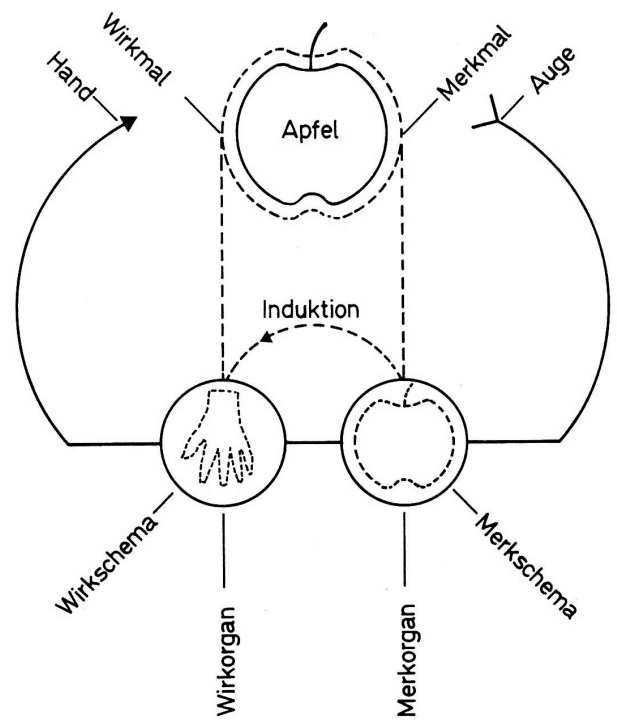

Figure 1. Function plan of an ape that grasps an apple (Uexküll 1931b, reprinted in Uexküll 1980: 329.).

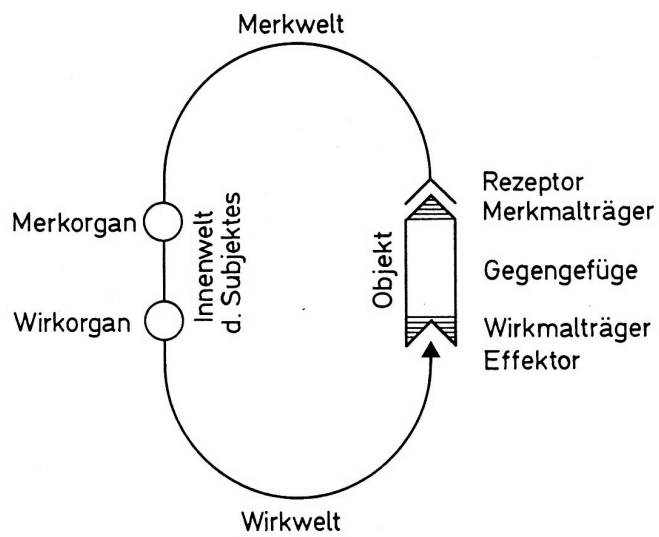

Figure 2. Scheme of a function circle (from Uexküll 1980: 330). 
In the organismic world, function circles appear in different, more or less complex "organizations". They extend from simple reflex arches to actions with multiple and interconnected reflex systems, and from unicellular organisms to men. In his Theoretische Biologie, Uexküll distinguishes between "instinct actions" (Instinkthandlungen), "plastic actions" (plastische Handlungen), "experience actions" (Erfahrungshandlungen) and "controlled actions" (kontrollierte Handlungen) (Uexküll 1928: 305-307). The differences between them depend mainly on the faculty of the subject to initiate the same action with different Merkmale. Reflexive capacities (for example memory, experience or analytical skills) can establish new "secondary clues". 67

Uexküll often refers to Pawlow's experiments as a "proof" for the plasticity of the Merkwelt. ${ }^{68}$

However, the "complementarity" of the Merkwelt and the Wirkwelt is a precondition for their regulation through an animal subject In this context. Uexküll often alludes to "life energies" (Lebensenergien) that express themselves in harmony. ${ }^{69}$ But he uses these terms only to point to an unknown "origin" of biological order. The best analogy to understand the origin of this order is, for Uexküll, the order that is produced through the composition of a melody or a symphony. ${ }^{70}$ Music thus comes into play when Uexküll wants to go beyond descriptions and proofs to sketch the "Planmäßigkeit of the world power that creates subjects" (Uexküll 1920b: 74).

\section{The "composition" of the world and its melody}

The Planmäßigkeit of the world is a "rule" to create order. Stimuli and impulses are "both expressions of the same self-acting cell dynamic" (Uexküll 1931a: 388), and this cell-dynamic expresses itself like an "I-tone" (Ich-Ton). The I-tone is the "self-tone" (Eigenton) of the cell, and not a "tone of use" or "usefulness" (Nutzton) as in human machines (Uexküll 1931a: 386).

\footnotetext{
67 Cf. Uexküll 1903: 390.

68 Cf. Uexküll 1928: 169-171, 305-306; and 1931a: 388.

69 Cf. Uexküll 1920a: 176-177.

70 Uexküll refers to this analogy throughout his Bedeutungslehre. Cf. Uexküll [1934] 1956: 105-159.
} 
Various receptor and effector cells are combined in "centers" that "direct" (leiten) the excitations in different "ways" (Bahnen). This "regulation" (Steuerung) is "influenced through the "mood' (Stimmung) of the whole, which can change periodically" (Uexküll 1920a: 175-176). The mood of the whole is "decisive" (ausschlaggebend) for the existence of "thresholds" that block excitation: "a low tension lets the stimulus in, a high tension dims it". ${ }^{71}$

The I-tone of an organism that acts in its specific Umwelt is not the result of a gradual "adaptation" (Anpassung) in time (as "Darwin" thought) or of the influence of the environment on the individual development of an organism (as "Lamarck" thought), but of its “adjustment" (Einpassung) ${ }^{72}$ :

We have to accept the fact that there are, on the one hand, the properties of the outer world that have no determining influence [on the development of the germ], and that there is, on the other hand, the living germ that has no organs which could inform it about these properties. However, we can see that the germ produces with complete certitude certain anti-properties that are adjusted to a group of certain properties in the outer world. (Uexküll 1928: 321) ${ }^{73}$

Organisms "fit" into their Umwelt through their receptor and effector organs as the "joints" (Fugen) and "tenons" (Zapfen) of a harmonizing plan. ${ }^{74}$ For Uexküll, it is a "wonderful fact" (wunderbare Tatsache) that "there are in the outer world certain properties (Eigenschaften) in a limited number, for which the animal must, if it is supposed to thrive, form certain anti-properties (Gegeneigenschaften) in its corporal construction that fit as joints and tenons into the outer world" (Uexküll 1928: 320). Each anti-property of the animal subject always fits into a "group of properties" in the Umwelt (Uexküll 1928: 321). Conversely, the Umwelt represents from the perspective of the subject the "complementary properties" or the "Gegengefüge" of its own properties. $^{75}$

71 Cf. Uexküll 1920a: 176 and 1931a: 391.

72 Cf. Uexküll 1928: 317-321.

73 Cf. Uexküll 1928: 317-321. Uexküll thought that the impulse series can be "excited" (angeregt), but not "created" (gebildet) from external influences (Uexküll 1928: 313).

74 Cf. Uexküll 1920a: 176.

75 Cf. Uexküll 1920b: 76: "Each property of a living being has its complementary property in the Umwelt to accomplish the relation (um die Beziehung voll zu machen)". See also Uexküll 1927: 20-21. 
Each "gene" is "interwoven" (verflochten) in the Planmäßigkeit of the animal subject, and each property that expresses the "gene" during the development of the animal subject also has a complementary property in the Umwelt of that subject. However, in "biological relationships" properties of the subject can be "bound" to multiple complementary properties, and different subjects "use" (verwerten) these options individually to create "richer" or "poorer" Umwelten. ${ }^{76}$ All Umwelten "fit" again into each other, although no Itone "acts" for the expression of other I-tones. Organisms live in their proper "worlds", and yet every "world" is part of a universal harmony in which an individual construction plan can appear as a variation of one of the same "species":

It can be proved that, on the one hand, each organism has a different Umwelt to which it is adjusted with accuracy, and that, on the other hand, its relations to other organisms fit not only into [their] external properties but also into [their] construction plans. (Uexküll 1927: 21)

The unity of each organismic plan that integrates formation and construction plans corresponds to the unique role that the adult organism plays in the universal harmony of all plans, and the universal harmony depends solely on the Weltplan and its creator. ${ }^{7}$

Uexküll makes very clear that explanations of "biological relations" refer ultimately to metaphysical and religious assumptions or Weltanschauungen. ${ }^{78}$ However, a conscious choice of a Weltanschauung has to respect scientific descriptions and experimental proofs. For Uexküll, these descriptions and proofs tend rather to vitalistic than to mechanistic positions. ${ }^{79}$ In his technical biology, the "adjustment" of the animal subject to the common world of all organisms is the "goal" of its self-differentiation. Such a goal is not a "purpose" that depends on imagination, but the main "natural" property of the subject as an expression of its "plan". 80

According to this "plan", receptor and effector organs fit into Umwelten as "joints" and "tenons". But organic joints and tenons are not part of a clockwork with fixed mechanical relations. Rather, the

\footnotetext{
76 Cf. Uexküll 1920b: 85 and 1928: 320.

77 Cf. Uexküll 1931a: 391.

78 Cf. Uexküll 1927: 25, and 1923.

79 Cf. ibid., pp. 8-12. Uexküll also criticizes vitalistic positions (cf. ibid.).

80 Cf. Uexküll 1928: 320-321. See also Langthaler 1992: 75-92.
} 
"interweavement" (Verflechtung) and relatedness of I-tones depend on the "autonomous center" of the organism, the nucleus, that "acts" like a "piano of ferments" (Fermentklavier) on which the impulse series plays for itself the "melody of formation" (Gestaltungsmelodie) and the "melody of construction" (Baumelodie). Both melodies are part of the same "organismic symphony". 11 This baroque composition "regulates" the opposition between the double bass like "mood" (Stimmung) and the partial I-tones of organs and cells, the contrapuntal juxtaposition of Merkzeichen and Wirkzeichen in Umwelten and the complementarity of all organismic plans in inorganic environments. ${ }^{82}$

Uexküll was convinced that the manifold of Umwelten had increased during the phylogeny of organic bodies. This increase of new Umwelten and their subjects never happens for Uexküll "gradually", but in "leaps" (Sprüngen). Changes of "parts" in the construction plan of organisms would destroy their "functioning". 83

In a similar way, Leibniz thought of the world as the production of a God who searched for the best rational criteria for variety in unity. The solution was a network of "ideal machines" that independently produce and reproduce themselves as "automatons". The effect of their permanent reproduction is a growing variety in time according to a single rule that governs

Within the manifold of Uexküll's Umwelten, all organisms are, as in Leibniz's monadic system, "equally perfect" as natural subjects that are able to exist, although the "adjustment" of higher organisms is more multifarious. ${ }^{84}$ There are thus "poorer" and "richer" Umwelten, and their richness depends on individual potentials to perceive and act. This potential is predetermined through the subject's "plan" and does not depend on its reflexive faculties and cultural environments. However, it can only be expressed if the respective framework of the Gegengefüge is present.

81 Cf. Uexküll 1903: 276; 1920b: 72-73; 1922: 140 and 1928: 172-173, 184, 295-296. Uexküll also refers to a "melody of impulses" (1928: 313) and a "melody of metabolism" (1928: 296).

82 Cf. Uexküll [1934] 1956: 145-149.

83 Cf. Uexküll 1928: 290-291.

84 Cf. Uexküll 1920a: 177. For the role of the double perfection of organismic order in the natural history and philosophy of the 18th and 19th century, see Cheung 2001 and 2000b. 


\section{Conclusion}

Uexküll's technique of nature is a theory of organic order that refers to experimental settings in research fields that focus on reflex mechanisms and cell development. Hans Driesch's experiments on the prospective and actual potential of embryonic cells and Hans Spemann's experiments on the induction of organizing effects represent for Uexküll two "proofs" for the existence of "immaterial factors" that "regulate" organismic development.

The temporal order of such a regulation can only be explained through an "active plan" and its impulse series that initiate the release of ferments. Ferments are stored and bundled in the "genes" of the nucleus that "act" as subordinated natural "factors" with specific "properties" within the cell. Activated through the impulse series, they release ferments which are necessary for the construction and deconstruction of the cells and for their development into a "close functional unit" of correlated organs. However, constructive and deconstructive processes "act" according to the same general scheme of "action". As a "function circle", this scheme can also be applied to the relation between the organism and its Umwelt of Merkzeichen und Wirkzeichen. The "big question of the future" is thus for Uexküll, "if it will be experimentally possible to isolate impulses and to force them to act on other substances than the protoplasm" (Uexküll 1920b: 178).

In his theory of a technique of nature as a necessary condition for the development and existence of organismic subjects, Uexküll also reinterprets evolutionary problems. For Uexküll, neither Darwinian adaptations nor gradual neolamarckian transformations can explain the inductive and functional aspects of plans that regulate individually metabolistic, perceptive and mechanical processes. Rather, the "composition" of plans and their harmony in a Weltplan is a necessary, though non-scientific precondition for the existence of organisms. Ultimately, this ordering order or "organization" can only be understood in analogy with the composition of a "melody" that is composed of individual tones or I-tones. Each set of tones needs a complementary set of tones to express its own "melody" within the "symphony" of all.

Uexküll's theory of a technique of nature thus reestablishes the problematic settings of older discursive formations. ${ }^{85}$ The relation between partial and general plans that regulate the formation of the

85 Cf. Cheung 2000, 2004a and 2004b. 
"living germ" could be interpreted as a reformulation of Charles Bonnet's theory of germ-fiber-units, and the necessary "leap" from one construction plan to the other refers clearly to Georges Cuvier's comparative anatomy and his organizational types.

The philosophical framework of Uexküll's theory of a technique of nature depends on problems that are related to Leibniz's monadology, rather than to Kant's Critiques. ${ }^{86}$ Uexküll uses Kant's notion of 'schemes' that mediate between perception and judgment, but the pivotal point of his theory is centered around the "natural" conditions of self-differentiating entities and the harmonic "complementarity" of their "perspectives".

Uexküll pointed clearly to the problem that explanations of regulative processes have to refer to sign theories of mediating material processes and informing "agents". The rule of the subject could thus be interpreted as an active code that produces the conditions of its readability and of its coordinating influence during developmental and metabolistic processes itself. The code aspect of Uexküll's theory is also related to the notion of complementarity and Gegengefüge. The expression of the organismic subject, its development and existence, involves an active and reactive exchange with other subjects on multiple organizing levels. Intersubjectivity is thus necessary for the existence of animal and human subjects. However, intersubjective relations are limited through the respective set of rules and their range of possible applications that are predetermined by the overall organismic plan. Uexküll's theory of organic order thus unfolds, in a biological perspective, the Leibnitian problem of monadic worlds. The problem of subjectivity and intersubjectivity, however, is part of a larger and long-lasting discursive transformation in the first half of the twentieth century. Husserl, Cassirer and Heidegger address similar problems to Uexküll, but offer different solutions.

For a detailed discussion of the philosophical context and framework of Uexküll's theory see Langthaler 1992. 


\section{References}

Canguilhem, Georges 1981. La formation du concept de régulation biologique aux XVIIIe et XIXe siècle. In: Canguilhem, Georges, Idéologie et rationalité dans l'histoire des sciences de la vie. 2nd ed. [1st ed. 1977] Paris: Vrin, 81-99.

Cheung, Tobias 2000. Die Organisation des Lebendigen. Die Entstehung des biologischen Organismusbegriffs bei Cuvier, Leibniz und Kant. Frankfurt am Main: Campus 2000.

- 2001. Cuvier et la perfection du parfait. Revue d'Histoire des siences 4: 543553.

- 2004a. Die Ordnung des Organischen. Zur Begriffsgeschichte organismischer Einheit bei Charles Bonnet, Spinoza und Leibniz. Archiv für Begriffsgeschichte 54. (in press)

- 2004b. Bonnets Systemtheorie organismischer Ordnung. Journal of the History and Philosophy of Ideas. (in press)

Driesch, Hans 1892. Entwicklungsmechanische Studien I. Der Werth der beiden ersten Furchungszellen in der Echinodermenentwicklung. Experimentelle Erzeugung von Theil- und Doppelbildungen. Zeitschrift fur wissenschaftliche Zoologie 53: 160-178.

Duchesneau, François: 1998. Les modèles du vivant de Descartes à Leibniz. Paris: Vrin.

Fässler, Peter E. 1995. Hans Spemann (1869-1941) - Experimentelle Forschung im Spannungsfeld von Empirie und Theorie. Ein Beitrag zur Geschichte der Entwicklungsphysiologie zu Beginn des 20. Jahrhunderts. Berlin/Heidelberg: Springer Verlag 1997.

Kull, Kalevi 1998. On semiosis, Umwelt, and semiosphere. Semiotica 120: 299310 .

Langthaler, Rudolf 1992. Organismus und Umwelt. Die biologische Umweltlehre im Spiegel traditioneller Naturphilosophie. Hildesheim/Zürich/New York: Olms Verlag.

Mocek, Reinhard 1998. Die werdende Form - Eine Geschichte der kausalen Morphologie. Marburg an der Lahn: Basilisken-Presse.

Moore, John. A. 1972. Heredity and Development. 2nd ed. New York: Oxford University Press.

Penzlin, Heinz 2000. Die Entwicklungsphysiologie. In: Ilse Jahn (ed.), Geschichte der Biologie. Theorien, Methoden, Institutionen, Kurzbiographien. 3rd ed. Heidelberg: Spektrum Akademischer Verlag. 441-460.

Uexküll, Jakob von 1903. Studien über den Tonus I. Der biologische Bauplan von Sipunculus nudus. Zeitschrift für Biologie 44: 269-344.

- 1905. Leitfaden in das Studium der experimentellen Biologie der Wassertiere. Wiesbaden: J.F. Bergmann.

- 1909. Umwelt und Innenwelt der Tiere. Berlin: J. Springer.

- 1920a. 'Die Lebensenergie'. In: J. von Uexküll, Kompositionslehre der Natur. Biologie als undogmatische Wissenschaft. Edited by Thure von Uexküll. Frankfurt am Main: Ullstein Verlag 1980, 175-179. [Originally published in 
J. v. Uexküll: 1920. Theoretische Biologie. Berlin: Verlag Gebrüder Paetel, 251-256.]

- 1920b. Biologische Briefe an eine Dame. Berlin: Verlag Gebrüder Paetel.

- 1921. Umwelt und Innenwelt der Tiere. 2nd ed. Berlin: J. Springer.

- 1922. Technische und mechanische Biologie. Ergebnisse der Physiologie 20: $129-161$.

- 1923. Mechanik und Formbildung. Deutsche Rundschau 201: 51-64.

- 1926. Ist das Tier eine Maschine?'. Bausteine für Leben und Weltanschauung von Denkern alter Zeiten 4: 177-182.

- 1927. Definition des Lebens und des Organismus. In: A. Bethe, A.; Bergmann, G. von; Embden, G.; Ellinger, A. (eds.), Handbuch der normalen und pathologischen Physiologie: Mit Berücksichtigung der experimentellen Pharmakologie. Berlin: J. Springer, vol. 1, 1-25.

- 1928. Theoretische Biologie. 2nd ed. Berlin: J. Springer.

- 1929. Plan und Induktion. Archiv für Entwicklungsmechanik der Organismen 116: 36-43. [festschrift for Hans Spemann]

- 1931a. Die Rolle des Subjekts in der Biologie. Die Naturwissenschaften 19: 385-391.

- 1931b. Der Organismus und die Umwelt. In: Driesch, Hans; Woltereck, H. (eds.), Das Lebensproblem im Lichte der modernen Forschung. Leipzig: Quelle \& Meyer, 189-224.

- 1938. Das Werden der Organismen und die Wunder der Gene. In: Dennert, Eberhard (ed.), Die Natur - das Wunder Gottes. Berlin: Verlag Martin Warnek, 135-144.

- 1980. Kompositionslehre der Natur. Biologie als undogmatische Wissenschaft. Edited by Thure von Uexküll. Frankfurt am Main: Ullstein Verlag.

Uexküll, Jakob von; Kriszat, Georg 1956 [1934]. Streifzüge durch die Umwelten von Tieren und Menschen: Ein Bilderbuch unsichtbarer Welten. Berlin: J.Springer.

\section{От протоплазмы до умвельта: планы и природная техника в теории порядка организмов Якоба фон Юкскюлла}

Для Якоба фон Юкскюлла биология является наукой об организации живых существ. В контексте механики развития (Entwicklungsmechanik) он указывает на опыты X. Дриша и X. Шпеманна над эмбриональными зародышевыми клетками как на доказательство того, что организмы являются природными объектами, формирующимися в процессе самодифференциации. Юкскюлл сосредоточен именно на этой теории самодифференциации или упорядоченности. В понятие упорядоченности он включает и “технику природы", которая способна структурировать органический и анорганический материал в соответствии с планами и правилами. Эти планы и 
правила являются частью порядка всего универсума. Как предсуществующие системы знаков или коды они определяют и регулируют развитие и существование отдельных животных субъектов в специфических, им присущих Umwelt'ax.

\section{Protoplasmast omailmani: Plaanid ja loodustehnika Jakob von Uexkülli organismilise korra teoorias}

Jakob von Uexkülli jaoks on bioloogia teadus elusolendite organiseeritusest. Arengumehhaanika (Entwicklungsmechanik) kontekstis viitab ta H. Drieschi ja H. Spemanni katsetele embrüonaalsete idurakkudega, tõestamaks, et organismid on diferentseerumise poolt moodustatavad looduslikud objektid. Uexküll keskendubki just sellisele diferentseerumiste või organiseerituste teooriale. Organiseerituse mõistesse on tema jaoks kaasatud "looduse tehnika", mis on suuteline struktureerima orgaanilist ja anorgaanilist materjali vastavalt plaanidele ja reeglitele. Need plaanid ja reeglid moodustavad osa kogu maailma korrastusest. Eelnevalt olemasolevate märgisüsteemide või koodidena määravad ja reguleerivad nad üksikute loomsubjektide arengut ja eksistentsi nendele eriomastes omailmades. 